\title{
堆積作用がある場合のプレート生長
}

\author{
一日本海への適用— \\ 金沢大学理学部地学教室 河野芳輝 天野雅央 \\ (昭和 52 年 3 月 9 日受理, 3 月 19 日再受理)
}

\section{Thickening Plate Model with Sedimentation}

\author{
Yoshiteru KoNo and Masao Amano \\ Department of Earth Sciences, Faculty of Science, \\ Kanazawa University
}

(Received on March 9, 1977, Revised on March 19)

The effects of sedimentation on the thickening process of the lithospheric plate and surface heat flow are examined numerically. For this purpose, we revised the program for the thickening plate model which was used by KoNo and YosHII (1975) to take sedimentation into account.

The results are as follows:

(1) The effect of sedimentation is negligible when the sedimentation rate is smaller than $10^{-4} \mathrm{~cm} / \mathrm{yr}$, which is a typical rate for the ocean basins.

(2) There is, therefore, no need to revise the results of Kono and YosHII (1975) and YosHII et al. (1976), which were calculated neglecting sedimentation.

(3) However, when the sedimentation rate is as high as $5 \times 10^{-3} \mathrm{~cm} / \mathrm{yr}$, which is some times realized in the marginal seas and ocean basins near continents, the surface heat flow is decreased considerably.

(4) The sedimentation prevents the thickening of the plate, but this effect is very small compared with the effect on the surface heat flow.

We applied the present model to describe the origin and development of the Japan Sea, a typical example of a maginal sea, to its present state. Two cases were considered for a date of opening of the Japan Basin; the first assume a date of opening of $25 \mathrm{M}$. Y. B. P. (Miocene) and the second a date of 50 M. Y. B. P. (Palaeogene). The calculations present favorable results for the hypothesis that the Japan Sea opened at about 25 M. Y. B. P. If, however, we take the uncertainty of the parameters used in the present article into consideration, it is difficult to conclude that the opening time of the Japan Sea is in Miocene time only from the present calculations. Therefore, we concluded that whether the opening of the Japan Sea is in Miocene or Palaeogene times, the history of the Japan Sea, based on the thickening plate model, is consistent with the present geophysical and geological observations.

\section{§1. はじめに}

大洋に括ける地表熱流量や水深が海洋底の年代の平方根にそれぞれ反比例および比例して变

* 昭和 49 年 10 月 13 日 地震学会に执いて発表 
化するという関係が観測結果より見い出された。この関係を説明するモデルとして，「Cooling Plate Model*」 (McKenzie, 1967; Sclater and Franchetead, 1970), 「Boundary Layer Theory」(OXBURGH and TURCOTTE, 1968) が報告されている. 一方，海洋プレートの厚さと 年代の間にも，その後同様な結果が LEEDS et al. (1974), SCHLUE and KNOPOFF (1976), YOSHII (1975) によつて報告された。これらの関係を統一的に説明するモデルとして，YosHII により，「プレート生長モデル」(YoSHII，1973）が提案され，彼拈よびその共同研究者によつ て発展させられてきた (ITO, 1976; KoKo and YoshII, 1975; YosHII et al., 1976; 吉井他, 1975). 同様なモデルが PARker and Oldenburg (1973), Oldendurg (1975), Crough (1975), CROUGH and THOMPSON (1976) によつて発表されている. このモデルは, プレート はアセノスフェアの固化によつて生長すると主張している。しかし上記のモデルでは堆積物の 存在を無視して議論を展開していた．確かに海盆地域程度の堆積速度 $\left(10^{-4} \mathrm{~cm} / \mathrm{yr}\right.$ のオーダー) であればあまり地表熱流量に影響しないと予想される。しかしどの程度影響しないのかチェッ クする必要がある。 また縁辺海のように堆積速度の大きい $\left(10^{-3} \sim 10^{-1} \mathrm{~cm} / \mathrm{yr}\right.$ のオーダー) 地 域では，上記のモデルで無視されてきた堆積速度が地表熱流量やプレート生長に少なからず影 響すると考えられる，そこで上記のモデルを基本にして，海洋・縁辺海で実際に生じている堆 作用を考慮に入れたモデルを考え，地表熱流量就よびプレートの生長がどの程度堆積作用によ つて影響をらけるかを調べた。

日本海は縁辺海の一例であり，海盈地域に比べて堆積速度は大きい，縁辺海の生成および発 展の問題にプレート生長モデルを適用することを試み, 日本海の発達史をこのモデルから考察 してみた。

本論文では「リソスフェア」を「プレート」と略し，地殼とアセノスフェアにはさまれたプ レート部分を「マントルプレート」と略した。

\section{§2. モデルと基本式}

海洋プレートに称ける生長モデルはすでに ITO (1976), KONO and YoSHII (1975), YoSHII (1973), 吉井他 (1975), YoSHII et al. (1976)により報告されている.すなわち，(1)アセノスフ ェアからの熱流 $\left(Q_{0}\right)$, (2)プレートーアセノスフェア境界での潜熱の解放 $(\rho L \Delta l / \Delta t)$, (3)プレート 内の熱伝導 $(-K d T / d z)$ による冷却，以上のような熱収支のもとでアセノスフェア物質がプレ 一ト底部で固化し，プレートが時間と共に次第に厚くなるというモデルである (Fig. 1参照)。

KONO and AMANO (1977) は海洋プレートモデルを拡張し. 大陸性地殼構造（カコウ岩質

\footnotetext{
* Shrinking Plate Model と呼ぶのが正しいかもしれない.
} 
層，ゲンブ岩質層)，地殼内の放射性元素の分布と壊变，及び表面での浸蝕作用によるそれら の変化などを考慮に入れて，KONO and YOSHII (1975) と同様な計算を行つた（Fig. 2(a)). その結果，(1)大陸と海洋とで地表熱流量の平均値がほぼ等しいこと，(2)大陸地域に和ける基 盤の年代（最終的な熱的現象からの年代） $t$ と熱流量との関係が海洋と同様に $\sqrt{t}$ に反比例 し，その熱的減衰は大陸の方が海洋より約 10 倍小さいことを統一的に説明した.

今回のモデルは大陸プレートモデルでのカコウ岩質層およびゲンブ岩質層の代わりに，堆積 層, 海洋性地殼の 2 層構造を，表面での浸蝕作用の代わりに堆積作用を考慮したモデルである (Fig. 1). その他の仮定は KoNO and YosHII (1975) による海洋プレートモデルと同じであ る。すなわち，a）上部アセノスフェアは部分 溶融状態である，b）アセノスフェアの固化温 度は圧力に依存しない。c）アセノスフェアか らの熱流は時間的，空間的に一定である。d) それぞれの層内の物性值は時間, 空間, 温度お よび圧力に依存しなく一定である。 e) プレー ト内の相変化は考慮しない.

数学的にはマントルプレートーアスノスフェ ア境界での潜熱の解放に伴う一次元 3 層の非定 常熱伝導方程式を解くことに相当する.

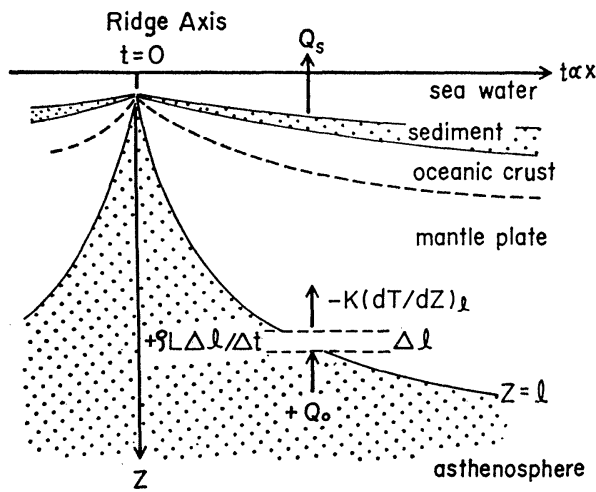

Fig. 1. Thickening model of the oceanic plate with sedimentation. $L$ : Latent heat of the asthenosphric material. $\psi_{0}$ : Heat flow from the asthenosphere. $\Delta l / \Delta t$ : Rate of plate thickening.

基本式は，

$$
\rho C(\partial T / \partial t)=K \partial^{2} T / \partial Z^{2}+H
$$

である.ただし堆積層内は (1) 式の右辺に堆積速度 $U$ を考慮に入れた項

$$
-U \rho C(\partial T / \partial Z)
$$

を加觉ている。

境界条件は，

$$
\text { 表面 ; } T=0
$$

堆積物一地殼境界;

$$
T_{s}=T_{c}, K_{s}(\partial T / \partial Z)=K_{c}(\partial T / \partial Z)
$$

地殼一マントルプレート境界；

$$
T_{c}=T_{p}, K_{c}(\partial T / \partial Z)=K_{p}(\partial T / \partial Z)
$$

マントルプレートーアセノスフェア境界 $(Z=l)$; 


$$
T=T_{s o l}, \rho L(d l / d T)=K_{p}(\partial T / \partial Z)-Q_{0}
$$

初期条件は，

$$
t=0 ; z=l_{0}
$$

初期温度 $T_{0}$ は層内の熱流量が全て等しいとした条件で求められる定常温度分布である。す なわち

$$
K_{p} d T_{0} / d z=-Q
$$

ここで $\rho:$ 密度, $C:$ 比熱, $K$ : 熱伝導率, $H:$ 放射性発熱量, $T:$ 温度, $t:$ 時間, $z:$ 厚さ, $T_{s o l}$ : 固化温度, $L:$ アセノフェア物質の固化熱, $Q_{0}:$ アセノスフェアからの熱流, $Q$ : 層内 の熱流， $l_{0}$ : 初期のプレートの厚さとする。 また $K, T$ の添字 $s, c, p$ はそれぞれ堆積層, 海 洋地殼, マントルプレートを表わす.

その他の条件は, 堆積層に対して

$$
\partial z_{s} / \partial t=U
$$

ここで $z_{s}$ : 堆積物の厚さ， $U$ : 堆積速度である.

アイソスタシーが常に成り立つていれば, 水深 $w$ はプレートの生長に伴つて変化していく;

$$
w=\left(\left(\rho_{s}-\rho_{a}\right) \cdot z_{s}+\left(\rho_{p}-\rho_{a}\right)\left(l-l_{0}\right)\right) /\left(\rho_{a}-\rho_{w}\right)+w_{0}
$$

ここで $\rho_{a}, \rho_{w}$ はそれぞれアセノスフェア, 海水の密度である。 $w_{0}$ はプレート生長の初期の 水深であり, 海嶺に対しては約 $2.5 \mathrm{~km}$ である.

（1）式を陽解法で差分化し，(2)から(9)の条件のもとで数値計算をした．計算に用いた空間 格子間隔および時間格子間隔は Table 1 に示す. (1) 式の安定係数が $(K / \rho C) \Delta t / \Delta z^{2}<0.05$ に なるようにこれらの数值を選んだ.

\section{§3. パラメター}

計算に用いたパラメターを Table 1 に示す。これらのうち, 特にマントルプレートの熱伝 導率 $\left(K_{p}\right)$, アセノスフェア物質の潜熱 $(L)$, アセノスフェアからの熱流 $\left(Q_{0}\right)$ はよくわかつて いない量である上に, 地表熱流量, プレートの厚さに大きな影響を及ぼす重要なパラメターで ある.これらのパラメターの効果はすでに KONO and YoSHII (1975) により調べられている. ここでは彼らと同じ值，すなわち $K_{p}=0.007 \mathrm{cal} / \mathrm{cm} \cdot \mathrm{sec} \cdot \mathrm{deg}, L=80 \mathrm{cal} / \mathrm{g}, Q_{0}=0.6 \mathrm{H} . \mathrm{F} . \mathrm{U}$. を用いた，堆積層内の発熱量 $\left(H_{s}\right)$ は主に生物による反応熱と放射性元素による崩壊熱が考光 られることから $1.0 \times 10^{-13} \mathrm{cal} / \mathrm{cm}^{3} \cdot \mathrm{sec}$ を用いた (REVELL and MAXWELL, 1956). 海洋地殼 は大部分ゲンブ岩質層とみなし，その放射性発熱量として $0.5 \times 10^{-13} \mathrm{cal} / \mathrm{cm}^{3} \cdot \mathrm{sec}$ (BULLARD, 1954)，マントルプレート内のそれは非常に小さいことから，KoNo and YosHII (1975) の結果 
Table 1. Values of the parameters used in the present calculations for open and marginal seas. A smaller grid interval of $0.025 \mathrm{~km}$ is employed in the computations, if the sedimentation rate is less than $10^{-4} \mathrm{~cm} / \mathrm{yr}$.

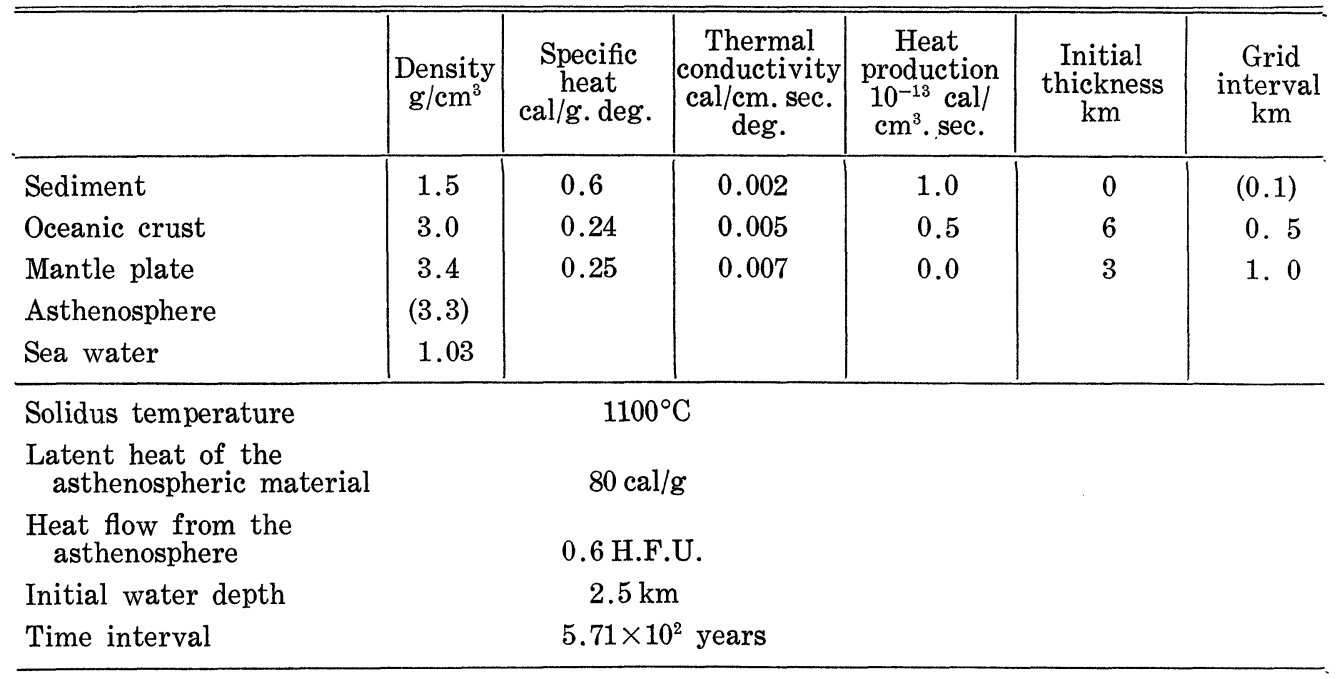

を参考にして，ここでは無視した．

堆積物の熱伝導率は地表熱流量測定において重要なパラメターであり，莫大な測定値がある. それらの平均值として $0.002 \mathrm{cal} / \mathrm{cm} \cdot \mathrm{sec} \cdot \mathrm{deg}$ を用いた。 をた，堆積物の比熱は水を $50 \%$ 以 上含むものとして，0.6 cal $/ \mathrm{g}^{\circ} \mathrm{C}$ を用いた (BULlaRD et al., 1956).

計算格子間隔は堆積層，海洋地殼層，マントルプレート層に执いて,それぞれ $100 \mathrm{~m}, 500 \mathrm{~m}$, $1 \mathrm{~km}$ とした。ただし，海盈のように非常に堆積速度の小さな $\left(10^{-4} \mathrm{~cm} / \mathrm{yr}\right.$ のオーダー) 場合 の計算には，堆積層のそれは $25 \mathrm{~m}$ とした。

Table 1 のパラメターを使つた海洋に拈けるプレート生長モデルの計算結果を Fig. $2(b)$ に 示す。この図は堆積速度を $5 \times 10^{-4} \mathrm{~cm} / \mathrm{yr}$ とした場合（実線で示す）と堆積物がない場合（点 線で示す）両者の地表熱流量，水深，プレートの厚さと年代の関係を示した図である，我々の 計算結果はこの図に示すように，それぞれの観測值を統一的に説明することができる。

\section{§4. 堆積作用がもたらす地表熱流量およびプレート生長への影響}

堆積物の厚さやその広がり方，さらに堆積速度などが実際の地表熱流量を減少させていると いうことは多数の研究者によつて指摘されている (ANDERSON et al., 1976; LISTER, 1972; Sclater et al., 1974; Sclater and Crowe, 1976; Von Herzen and Uyeda, 1963). 例 えば，VON HERZEN and UYEDA (1963) は一定速度の堆積，乱泥流や地汇りによる急激な堆 積，そして堆積層内の海水の循環等による地表熱流量への 影響を解析解によつて考察した. 


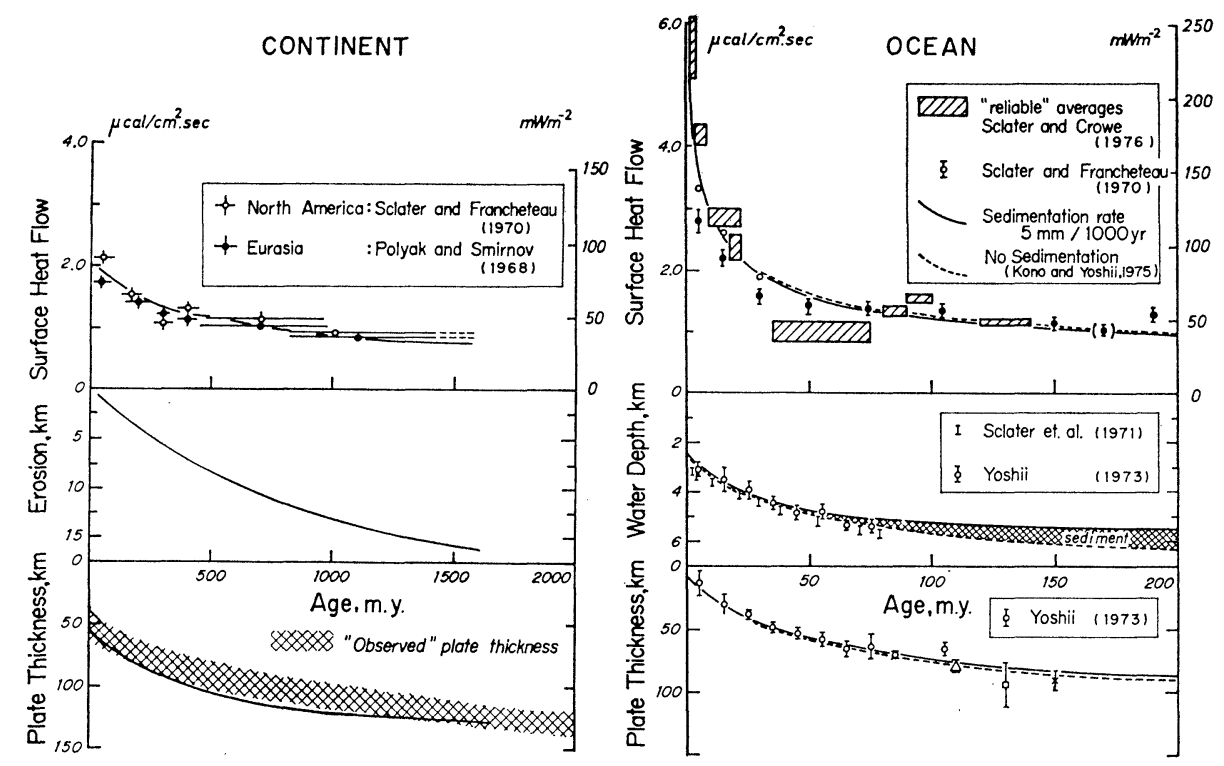

Fig. 2. Comparison of the continental model (a) (Kono and Amano, in preparation) with the present oceanic model (b).

(a) Surface heat flow, erosion (surface topography) and plate thickness (derived from Kono and Amano) versus basement age. The "observed plate thickness" shows a general tendency of the plate thickening with age inferred from seismic and gravimetric studies.

(b) Surface heat flow, water depth (topography) and plate thickness versus ocean floor ages derived from the present calculations and Kono and YosHII (1975). The "reliable" heat flow averages mean reliable estimates of conductive heat flow at depth (from Sclater et al. 1976, Fig. 7 (a)).

The solid and dotted lines represent the results for the present model assuming a constant sedimentation rate of $5 \mathrm{~mm} / 1000 \mathrm{yr}$ and no sedimentation for KoNo and YosHII (1975), respectively.

Hachured area indicates the sediment thickness.

The heat flow from the asthenosphere (0.6 H.F.U.) and the latent heat of the asthenospheric material $(80 \mathrm{cal} / \mathrm{g})$ are the same for both models.

SCLATER 達は海嶺近くでの地表熱流量の観測値が非常に分散する理由として, 海洋地殼層内の 熱水循環と堆積物の一様な分布とが密接な関係にあるということを報告している (ANDERSON et al., 1976; HYNDMAN et al., 1976; SCLATER and CROWE, 1976).すなわち，海額近くで の熱輸送は主として熱水循環でもたらされており，もし堆積物が一様に広く分布していなけれ ば，熱水循環による熱損失が大きく，その結果として実際の熱流量よりも低い值が観測される としている.

我々は VON HERZEN and UYEDA（1963）と同様に各層内の熱輸送を熱伝導だけによると 仮定し，一様な堆積速度がどの程度地表熱流量やプレート生長に影響するかをプレート生長モ デルの立場にたつて考察した。 その結果を Fig. 3 から Fig. 5 に示す. Fig. 3 は種々の堆 
積速度 $(U)$ に拈ける地表熱流量, 水深およびプレートの厚さ対海洋底年代の関係図である. Fig. 4 は堆積作用がない場合の地表熱流量を基準にして Fig. 3 を書きかえたものである. 参考として，VON HERZEN and UYEDA (1963) の解析結果を点線で示した。しかし我々の結 果は時間と共にプレートが生長している場合のものだから厳密には彼らの結果と比較できない. 堆積速度が大きいと両者の差が大きくなる原因はそこにある. Fig. 5 は Fig. 4 と同様に堆 積作用がない場合のプレートの厚さ $\left(z_{0}\right)$ を基準にして Fig. 3 を書きかえたものである。こ れらの計算結果から，次のようなことがいえる。

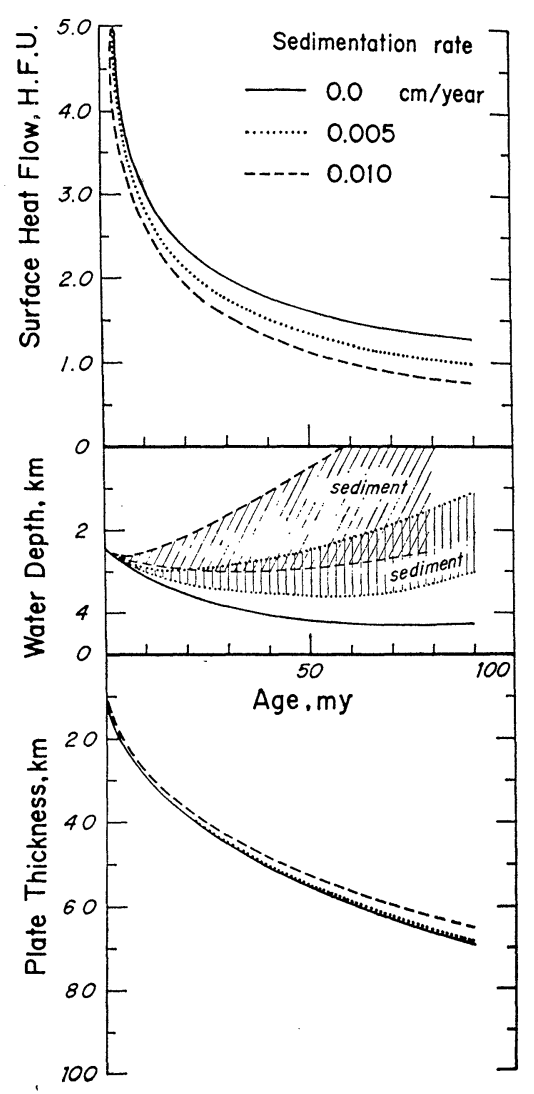

Fig. 3. Surface heat flow, topography and plate thickness versus age derived from the numerical experiments assuming several constant sedimentation rates.

Upper and lower lines in Water depth-Age figure represent the depth of surface topography and oceanic crust, respectively.
(1) 海盆地域のように堆積速度が小さい $\left(<5 \times 10^{-4} \mathrm{~cm} / \mathrm{yr}\right)$ 場合, 堆積物の存在は地表熱流 量にほとんど影響を和よぼさない。したがつて KONO and YOSHII (1975) などに示された堆積作 用がない場合の海洋プレート生長の結果は, 海嶺お よび深海盈地域に対しては訂正を加える必要がない，

（2）堆積速度の大きな地域 $\left(10^{-3} \mathrm{~cm} / \mathrm{yr} \sim 10^{-1}\right.$ $\mathrm{cm} / \mathrm{yr})$, 例觉ば堆積速度 $5 \times 10^{-3} \mathrm{~cm} / \mathrm{yr}$ では約 20 m.y. で $85 \%$ に減少させられる。さらに堆積速度 $5 \times 10^{-2} \mathrm{~cm} / \mathrm{yr}$ の場合には $10 \mathrm{~m} . \mathrm{y}$.で $55 \%$ に減少

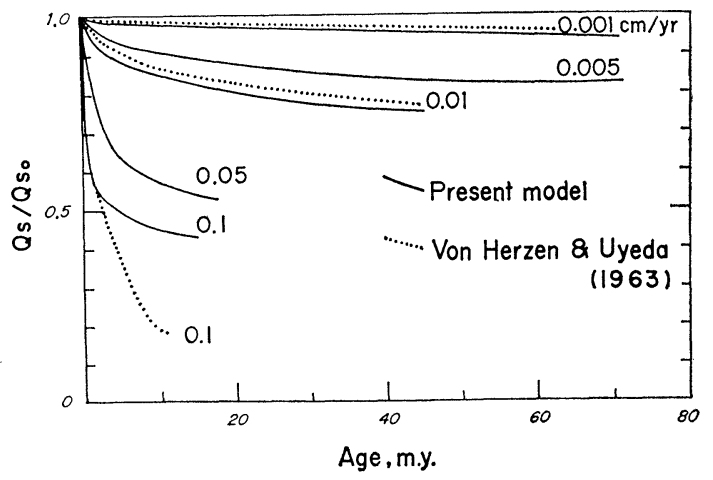

Fig. 4. Effect on the surface heat flow of various constant sedimentation rates. The ratio of $Q_{8}$ to $Q_{s 0}$ plotted against age. $Q_{s}$ is the surface heat flow assuming a constant sedimentation rate.

$Q_{\boldsymbol{s} 0}$ is the surface heat flow assuming no sedimentation.

The solid lines are the results of the present model while the dotted lines are from the results of Von Herzen and Uyeda, Fig. 9 (1963). 


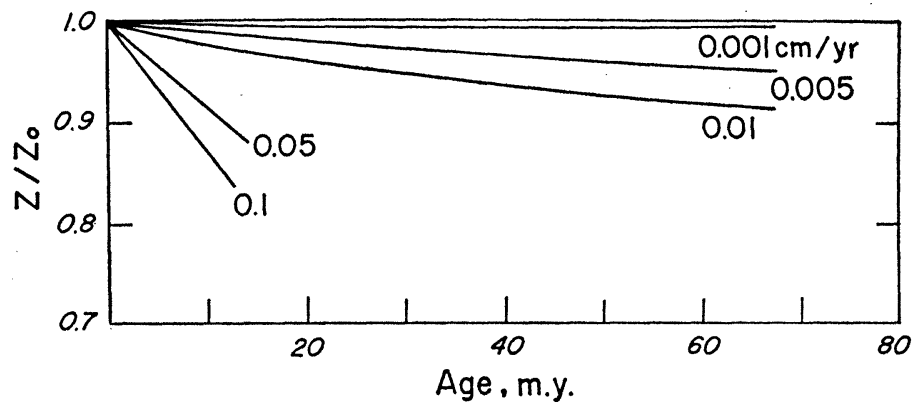

Fig. 5. Effect on the plate thickness of various constant sedimentation rates. The ratio of $Z$ to $Z_{o}$ is plotted against age, where $Z$ is the plate thickness assuming a constant sedimentation rate and $Z_{o}$ is the plate thickness assuming no sedimentation.

させられる。

（3）堆積速度のプレート生長への影響は地表熱流量のそれと比べて非常に小さい，現在の観 測結果の精度を考えるとその誤差内に落ちつく影響しか与えない。

以上のことから $5 \times 10^{-3} \mathrm{~cm} / \mathrm{yr}$ 以上の堆積速度の大きな地域の地表熱流量観測值は定常的な 熱流量を示しているのではなく，むしろ非常に減じられた值を示していることになる。

\section{$\S 5$. 日本海への適用}

プレート生長モデルは海洋地域の各種観測量を統一的に説明することに成功し, 海嶺海盆地 域がプレート生長のプロセスによつて発展していくことを確からしくすることができた。一方， 縁辺海の成因と発展についてはさまざまな見解があるが，それらは海嶺・海盆地域にお流るよ らに各種観測量を統一的に説明できるものであるかどうかの検討が加えられていない。ここで は縁辺海成因の物理的プロセスの考察はとりあえず議論の対象外として，ある物理条件が初期 条件として与えられたとき，その後の発展過程と現在の状態がプレート生長説によつて統一的 に理解しらるかぞうかを検討してみた。 もし，これに成功を拉さめれば，プレート生長が縁辺 海の発展を支配する重要なメカニズムである可能性を強く示すことになるし，成因についても 今までより進んだ見解をもつことができるようになるだろう。

そこで縁辺海の一例である日本海にこのモデルを適用し，その発達史を考察してみる．まず 日本海盆および大和堆*の主たる特徴をあげると，

（1） 日本海盆の平均熱流量は $2.23 \pm 0.52$ H.F.U. と一様に高く普通の海洋に比べて約 1 H.F.U. も高い。一方，大和堆は日本海盈のそれに比べて低く，約 1.8 H.F.U. である (YASUI et al., 1967).

\footnotetext{
* 北大和唯と大和堆を一括し, 大和海嶺のことをここでは大和堆と呼ぶ.
} 
（2）日本海盆の地殼構造は約 $6 \mathrm{~km}$ のゲンブ岩質層を持つ海洋型であり, 大和堆のそれは それぞれ約 $4 \mathrm{~km}$, 約 $10 \mathrm{~km}$ のカコウ岩質層, ゲンブ岩質層を持つ準大陸型の地殼を持つ(村 内, 1972).

（3）日本海盆における堆積物の構造はきわめ整然としており，その厚さも第一近似として 一様であり, 約 $2 \mathrm{~km}$ の厚さを持つ（村内，1972）. 大和堆での堆積物の厚さは数 $100 \mathrm{~m}$ である.

（4）日本海での堆積速度は非常に大きく約 $2 \sim 14 \times 10^{-3} \mathrm{~cm} / \mathrm{yr}$ である (DSDP, 1975).

（5）日本海盆の水深は約 $3.5 \mathrm{~km}$ であり，ほとんど平坦である．大和堆のそれは（北大和堆 と大和堆の平均水深) 約 $600 \mathrm{~m}$ である (HILDE and WAGEMAN, 1972).

（6）表面波分散の解析から得られる日本海域のプレートの厚さは約 $30 \mathrm{~km}$ である（ABE and KANAMORI, 1970).

（7）日本海に打ける地磁気異常は大洋に打けるとれと比べてはるかに弱く，かつ規則性も 弱い (ISEZAKI，1973)。このことは中央海盆のようなはつきりした拡大中心が存在しないこと を示している可能性が強い.

（8）現在の地質学的活動を示す現象（地震, 火山活動, 顕著な構造線など）が見られない. プレート生長説の立場から日本海の生成・発展を次のように考㝋てみた。 日本海には，かつ て活動した海嶺の存在は認められないし，堆積物の分布，地磁気異常の分布などからみても， 中央海嶺型の拡大中心をもつゆつくりとした拡大があつたとは認められない。したがつて，日 本海が拡大によつて生じたものとすれば，地質時代のある時期に，ごく短い期間(例えば $1 \mathrm{~m} . \mathrm{y}$. 程度）にほぼ現在の大ささまで拡大したと考える（このような短期間の拡大の原因については 現在, 説得力ある説をもつていない. しかし UYEDA and MIYASHIRO (1974) による活動的 海嶺のもぐりこみ，あるいは海洋プレートの重力的不安定によるプレートの break downは, このような結果をひきおこすであろう)。この時期には，日本海はその全域が中央海嶺型の構 造 (薄いプレートの厚さ, 高い熱流量, 浅い水深) をもつていたと考える. また, 大和堆は大 陸の破片として日本海盆の中央に残つた。 このような拡大以後，プレートの生長にともなつて， 日本海盆打よび大和堆の地域は水深を深め, 地表熱流量を減らしていつた。ここで述べた我々 の概念を Fig. 6 に図解した。

以上のような考方にたつて, 我々は, 日本海盆には海洋型, 大和唯には大陸型のプレート 生長モデルを適応し，海洋プレートと同様な計算を行なつた。計算に用いたパラメターは次の ようである. 日本海盈についてはアセノスフェアの密度以外はすべて Table 1 に示した值を

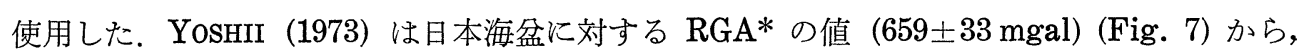

\footnotetext{
* Residual Gravity Anomalies： 上部マントル内の質量異常を示す一種のブーゲー異常
} 


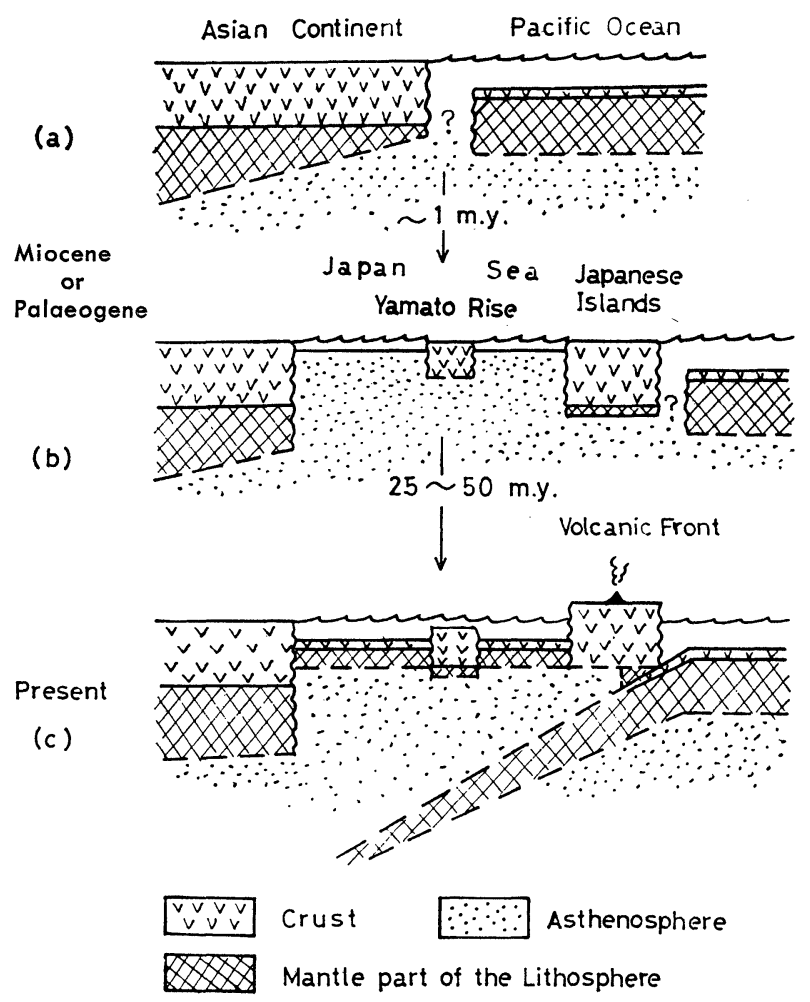

Fig. 6. Schematic illustration of our concept about the origin and development of the Japan Sea. From a structure shown in (a), the Japan Sea was formed at about either 25 m.y. B.P. (early Miocene) or 50 m.y. B.P. (middle Palaeogene) within a short period (say 1 m.y.) (b). After that, the lithospheric plate under the Japan Sea developed upto the present state (c) by the plate thickening process proposed by YosHII (1973).

日本海の生成時期が中新世であるなら，Parece Vela Basin と同様な上部マントル構造をも つ.すなわち，普通の海洋に比べて上部マントルは高密度であると指摘した．Fig. 8 (a) は堆 積速度 $U=0.008 \mathrm{~cm} / \mathrm{yr} \quad(25 \mathrm{~m} . \mathrm{y}$. で $2 \mathrm{~km}$ 堆積するとしてこの值を選んだ $)$ ， マントルプレー トーアセノスフェアの密度差を $0.15 \mathrm{~g} / \mathrm{cm}^{3}$ とした計算結果である. プレートの厚さの推定值 に $-5,+10 \mathrm{~km}$ 程度の自由度が見込まれるから，このモデルは互いに独立な 3 つの観測量 を全て満足しているといえる. 日本海の生成時期が $25 \mathrm{~m} . \mathrm{y}$. より若ければ観測量と理論値と の一致は一層良くなる，一方，日本海の生成時期を約 50 m.y. と仮定すると，日本海の RGA 值は Fig. 7 から推定されるように, 普通の海洋のスタンダードな RGA 值上にのる.このこ とは日本海の上部マントルも普通の海洋とほぼ同じ構造としてよいことを意味する，そこで， マントルプレートーアセノスフェアの密度差を大洋と同じ $0.1 \mathrm{~g} / \mathrm{cm}^{3}$ とした。 その結果を Fig. 8 (b) に示す. 50 m.y. に $2 \mathrm{~km}$ 堆積するとして, 堆積速度は $0.004 \mathrm{~cm} / \mathrm{yr}$ とした. 日本海の 


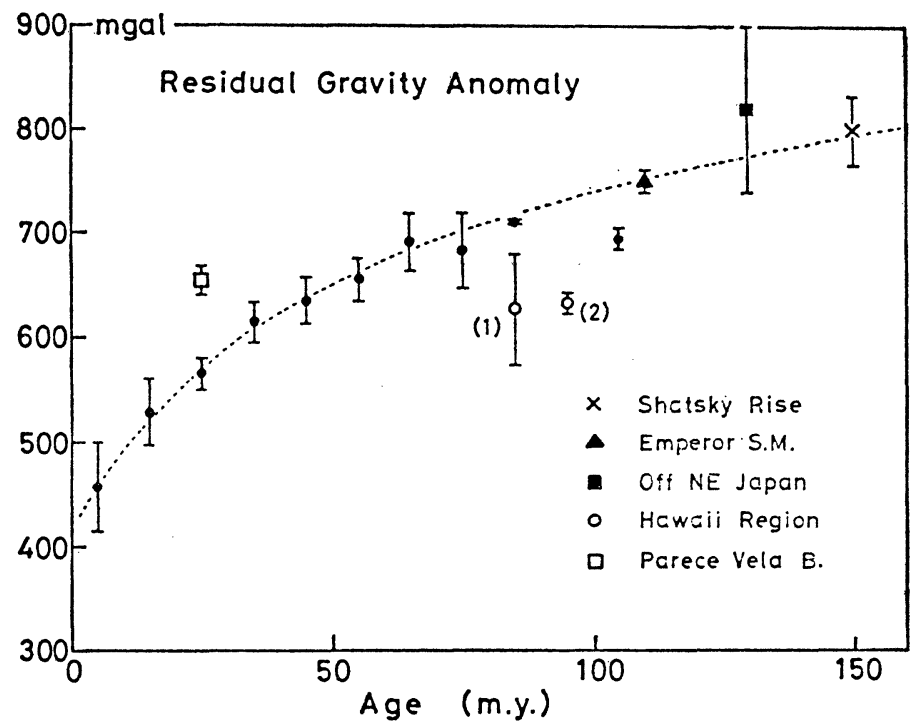

Fig. 7. The RGA versus age for the north Pacific and Parece Vela Basin (from YoshiI (1973), Fig. 6).

The RGA of the Parece Vera Basin is larger than the standard curve by 100 mgal.
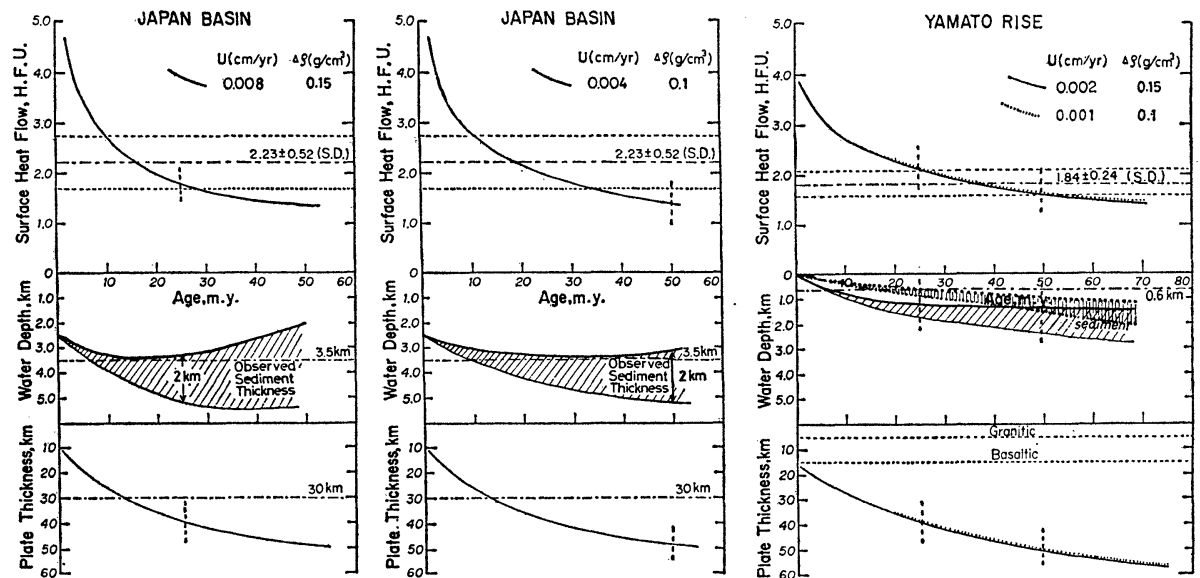

Fig. 8. Surface heat flow, topography and plate thickness versus ages derived from the numerical experiments for the Japan Basin and the Yamato Rise.

Shaded area indicates the sediment thickness. The dot-dash lines indicate the mean observed values.

(a) The formation of the Japan Sea is postulated to have occured 25 m.y. ago (Miocene). The sedimentation rate and the density gap between the mantle plate and asthenoshere are assumed to be $0.008 \mathrm{~cm} / \mathrm{yr}$ and $0.15 \mathrm{~g} / \mathrm{cm}^{3}$, respectively.

(b) The formation of the Japan Sea is postulated to have occured 50 m.y. age (Palaeogene). The sedimentation rate and the density gap are assumed to be $0.004 \mathrm{~cm} / \mathrm{yr}$ and 0.1 $\mathrm{g} / \mathrm{cm}^{3}$, respectively.

(c) The results of calculations for the Yamato Rise.

It is posulated that the Yamato Rise have had the subcontinental structure as a continental fragment since the opening time.

The solid and dotted lines represent the results assuming the density gap to be 0.15 and $0.1 \mathrm{~g} / \mathrm{cm}^{3}$, respectively. 
Table 2. Values of parameters used in the calculations for the Yamato Rise.

\begin{tabular}{|c|c|c|c|c|c|c|}
\hline & $\begin{array}{l}\text { Density } \\
\mathrm{g} / \mathrm{cm}^{3}\end{array}$ & $\begin{array}{c}\text { Specific } \\
\text { heat } \\
\text { cal/g. deg. }\end{array}$ & $\begin{array}{c}\text { Thermal } \\
\text { conductivity } \\
\text { cal } / \mathrm{cm}^{3} \text { sec. } \\
\text { deg. }\end{array}$ & $\begin{array}{l}\text { Heat } \\
\text { production } \\
10^{-13} \mathrm{cal} / \\
\mathrm{cm}^{3} . \mathrm{sec} .\end{array}$ & $\begin{array}{l}\text { Initial } \\
\text { thickness } \\
\text { km }\end{array}$ & $\begin{array}{c}\text { Grid } \\
\text { interval } \\
\mathrm{km}\end{array}$ \\
\hline Granitic layer & 2.6 & 0.23 & 0.005 & 3.0 & 4 & 0.5 \\
\hline Basaltic layer & 3.0 & 0.24 & 0.006 & 0.5 & 10 & 0.5 \\
\hline Mantle plate & 3.4 & 0.25 & 0.007 & 0.0 & 3 & 1.0 \\
\hline Asthenosphere & (3.3) & & & & & \\
\hline Sea water & 1.03 & & & & & \\
\hline \multicolumn{7}{|c|}{ Solidus temperature $\quad 1100^{\circ} \mathrm{C}$} \\
\hline \multicolumn{7}{|c|}{$\begin{array}{l}\text { Latent heat of the } \\
\text { asthenospheric material } \quad 80 \mathrm{cal}\end{array}$} \\
\hline \multicolumn{7}{|l|}{$\begin{array}{l}\text { Heat flow from the } \\
\text { asthenosphere }\end{array}$} \\
\hline Time interval & & $3.79 \times 1$ & $0^{3}$ years & & & \\
\hline
\end{tabular}

拡大生成時期を約 $50 \mathrm{~m} . \mathrm{y}$. と考えると，地表熱流量は観測值より低すぎ，プレートの厚さは 厚くなりすぎるよらにみえる，地表熱流量に関しての解釈は後に述べることにする。

大和堆についてのパラメターを Table 2 に示す。 大和堆は準大陸型の地殼をもつといらこ とから，初期のカコウ岩質層を $4 \mathrm{~km}$ ，ゲンブ岩質層を $10 \mathrm{~km}$ と仮定した，そして，プレート 生長につれてアイソスタシー均衡により沈降していつたと考えた. Fig. 8(c) にその計算結果を 示す。ただし，実線はマントルプレートーアセノスフェアの密度差を $0.15 \mathrm{~g} / \mathrm{cm}^{3}$ ，点線は 0.1 $\mathrm{g} / \mathrm{cm}^{3}$ とした場合の計算結果である。両モデルとも大和堆は日本海拡大のとき，とり残され， その後準大陸型の地殼をもつて生長していつたと考えても，各種観測値とはそれほど大きな矛 盾はない.なお，大和堆下のプレートの厚さについての情報はない.

日本海盆の地表熱流量は中新世の火成活動，あるいは KOBAYASHI and NOMURA (1972) が いら海底堆積物中の硫化物の酸化による発熱などによつて, 多少高められている可能性がある。 さらにスラブに沿つてのマグマ生成によつて日本海生成とは別の熱エネルギーが供給されてい る可能性も高い。また日本海盆下のプレートの厚さの推定値にも $-5 \mathrm{~km},+10 \mathrm{~km}$ 程度の自 由度があることを考慮する必要がある。

以上の結果は，日本海の進化の大勢がプレート生長説によつても理解できることを示してい る.さらに, 中新世ごろに日本海が形成されたとするモデルは, 地表熱流量・水深・プレート の厚さおよび重力などの観測量を全て満足することが明らかとなつた．このモデルにおいて， アセノスフェアからの熱流量 $Q_{0}$ やアセノスフェアの潜熱 $L$ は大洋・大陸プレート生長モデ ル (Fig. 2) と同じ值である。その意味でこのモデルは，大陸プレート生長モデルと統一的 (整合的)なモデルである。しかしながら， $Q_{0}, L$ などの值にも不確かさがあるので，これだ 
けの結果から, 日本海の生成時期を中新世ごろと結論づることは困難である. 特に, 次に述 ベる各種の資料を考慮に入れると, 日本海の生成が古第三紀ごろである可能性も残しておかな ければならない。

太平洋プレートの移動方向が東日本弧へ直交する方向に変化した時期は約 $42 \mathrm{~m} . \mathrm{y}$. 前 (JACKSON et al., 1975) といわれている.この時期から太平洋プレートが日本海溝から沈み込 み始めたという指摘がある (堀越, 1975). また古地磁気の研究から, 日本列島の折れ曲がりは白 亜紀以後, 古第三紀頃に日本海をふくらませる向きに扣こつたと考えることができる (KAWAI et al., 1971). また市川 (1972) は日本列島と朝鮮半島の地層の対比から, 日本列島の移動が あつたとすれば, $60 \mathrm{~m} . \mathrm{y}$. 前より新しく, $25 \mathrm{~m} . \mathrm{y}$. 以前の出来ごとであろうと示唆している. このようなことから, 日本海の拡大は $40 \sim 50 \mathrm{~m} . \mathrm{y}$. 前にほぼ現在の日本海程度までに (数 m.y. の時間内に一瞬に?) 拡大し, 日本海盆は海洋型, 大和堆は準大陸型の地殼になつた可能性が ある．日本海の生成が 25 m.y. B. P. ごろであるか 50 m.y. B. P. ごろであるかにかかわら ず, 日本海の地磁気異常が弱いことを説明する一つの可能性として, 拡大が地球磁場逆転期あ るいは正常期の一つの期間内に招こつたといら可能性を考えておく必要がある.

以上のよらに，我々は上述のプレート生長モデルが日本海に関する幾つかの基本的観測事実 を説明できることを示唆し，このモデルから解釈した日本海の発達史を考えてみた。 ここで最 も強調しておきたいことは縁辺海の一例である日本海においても, 海洋・大陸と同様なプレ一 ト生長のプロセスが成立しらるということである.

\section{§6. まとめと今後の問題}

我々が採用したプレート生長モデルからの一つの帰結は, 全地球的にみたとき, アセノスフ エア以深に大きな熱的不均質を仮定しなくてもよいといらことである。これは，従来広く流布 されたモデル（例えば，ClARK and RINGWOOD，1964; SClater and FRANCHETEAU, 1970) と根本的に異なつており, より単純である (Fig. 2 (a), (b)).

一様な堆積速度が地表熱流量とプレート生長にどの程度影響を与えるかといら問題に対して 我々は, 層内の熱輸送が伝導だけによるとして, プレート生長モデルの立場にたつて考察した. それによると, VON HERZEN and UYEDA (1963) の計算結果と同様に, 海盆地域における程 度の堆積速度 $\left(<5 \times 10^{-4} \mathrm{~cm} / \mathrm{yr}\right)$ では地表熱流量への影響を無視してもよい（地殼層内の熱水 循環が存在していると考えられている地域は除く)ことが確かめられた。 しかし堆積速度が海 盆地域の数倍もある，例えば縁辺海のような地域ではある程度の補正をしなければ信頼できる 值が得られない (Fig. 4)。堆積作用のプレート生長への影響は地表熱流量への影響に比べはる かに小さい (Fig. 5). 
縁辺海の発達史に関して，その一例である日本海について議論をした。それによると，日本 海は 25 50 m. y. 前のある時期に「一瞬」に拡大して，プレート生長のプロセスによつて現 在に至つていると考えられる (Fig. 8).

日本海が 25 m.y. 前に形成されたとするモデル. (Fig. 8 (a)) に比べると，50 m.y. 前に形 成されたとするモデル (Fig.8 (b)) は，観測量との一致がはるかに悪い，このことは，日本海 の生成を古第三紀あるいはそれ以前とするには，(1)ここで用いたプレート生長説のパラメター （特にアセノスフェアからの熱流量 $Q_{0}$ と潜熱 $L$ ) を大幅に変更するか，(2)これらのパラメタ 一を時間の関数とするか，あるいは(3)日本海のよらな縁辺海にはプレート生長説が適用できな いとするか，いずれかにしなければならないことを示している。いずれにせよ，縁辺海は大洋・ 大陸地域（両地域はシンプルなモデルで統一的に観測量が説明できることが明らかになつてい る (Fig. 2 および KONO and AMANO (1977) 参照)) とは非常に異なつた条件を持つている と考えなければならなくなる，これに対して，日本海の生成が中新世あるいはとれ以後であれ ば，日本海下のプレートは大洋・大陸地域のプレートと同じプロセス，同じ物理的条件のもと で生長してきたとして地表熱流量，水深，プレートの厚さ拈よび重力などの観測量を全て矛盾 なく説明できる。それにもかかわらず，我々のモデルを構成するパラメターにかなりの自由度 があることを理由に，日本海の生成時期を中新世ごろであると結論づけることは保留したい， したがつて日本海問題に対する本論文における最も重要な結論は, 日本海の進化と現在の状態 は，プレート生長説によつて統一的に理解できるという点である.

今後の課題として，オホーツク海，フィリピン海といら日本海と同様な，いわゆる縁辺海型 拡大と呼ばれている地域にも，我々のモデルでそれらの発達史を説明できるかどらかチェック する必要がある.

\section{謝 辞}

製図をしていただいた同教室の中村健二氏に感謝します。

文献

Abe K and H. Kanamori, 1970, Mantle Structure beneath the Japan Sea as revealed by Surface Waves, Bull. Earthq. Res. Inst., 49, 1011-1021.

Anderson, R. N. and M. A. Hobart, 1976, The Relation between Heat Flow, Sediment Thickness and age in the Eastern Pacific, J. Geophys. Res., 81, 3969-2989.

Bullard, E. C., 1954, The Flow of Heat through the Floor of the Atlantic Ocean, Proc. Roy. Soc. A222, 408-429.

Bullard, E. C., A. E. Maxwell and R. Reveld, 1956, Heat Flow through the Deep Sea Floor, in Advan. Geophys., 3, 153-181. 
Clark, S. P. and A. E. Ringwood, 1964, Density Distribution and Constitution of the Mantle, Rev. Geophys., 2, 35-88.

Crough, S. T., 1975, Thermal model of oceanic lithosphere. Nature, 256, 388-390.

Crough, S. T., and G. A. Thoppson, 1976, Thermal model of continental lithosphere. Jour. Geophys. Res. 81, 4857-4862.

DSDP, 1975, Initial Reports of the Deep Sea Drilling Project, Vol. XXXI.

堀越谼, 1975, 新生代造山運動と火山性鉱床のテクトニクス, 火山第 2 集, 20, 特別号, 341-353.

Hilde, T.W.C. and J. M. WAgEMAN, 1972, Structure and Origin of the Japan Sea, The Western Pacific, in Coleman, P. J. (ed.), Island Arcs, Marginal Seas, Geochemistry, Univ. W. Australia Press, 415-434.

Hyndman, R. D., R. P. Von Herzen, A. J. Erickson and J. Jolivet, 1976, Heat Flow Measurements in Deep Crustal Holes on the Mid-Atlantic Ridge, J. Geophys. Res., 81, 4053-4060.

市川浩一郎, 1972, 日本海域の復元によせて, 科学, 42, 630-633.

IsEZAKI, N., 1973, Geomagnetic Anomalies and Tectonics around the Japanese Islands, Oceanogr. Mag., 20, 65-72.

Iто, K., 1976, Heat Flow and Thickness of the Ocean Lithosphere, Earth Planet. Sci. Lett., 30, 65-70.

JACKson, E, D., H. R. SHAw and K. E. BARGAR, 1975, Calculated Geochronology and Stress Field Orientations along the Hawaiian Chain, Earth Planet. Sci. Lett., 26, 145-155.

Kawai, N., T. Nakajima and K. Hirooka, 1971, The Evolution of the Island Arc of Japan and the Formation of Granites in the Circum-Pacific Belt, J. Geoelectr., 23, 267-293.

Kobayashi, K. and M. Nomura, 1972, Iron Sulfides in the Sediment Cores from the Sea of Japan and their Geophysical Implications, Earth Planet. Sci. Lett., 16, 200-208.

Kono, Y. and T. Yoshil, 1975, Numerical Experiments on the Thickening Plate Model, J. Phys. Earth., 23, 63-75.

Kono, Y. and M. Amano, Thickening Model of Continental Lithosphere, (in preparation).

LEEDS, A. R., L. KNopoff and E. G. KAUSEL, 1974, Variation of upper Mantle Structure under the Pacific Ocean, Science, 186, 141-143.

Lister, C.R.B., 1972, On the Thermal Balance of a Mid-Ocean Ridge, Geophys. J. Roy. Astron. Sci., 25, 515-535.

McKenzie, D. P., 1967, Some Remarks on the Heat Flow and Gravity Anomalies, J. Geophys. Res., 72, 6261-6273.

村内必典, 1972, 人工地震探查による日本海の地殻構造, 科学, 42, 367-375.

Oldenburg, D. W., 1975, A Physical Model of the Creation of the Lithosphere, Geophys. J., 43, $425-451$.

Oxburgh, E. R. and D. L. TURCotT, 1968, Mid-Ocean Ridges and Geotherm Distribution during Mantle Convection, J. Geophys. Res., 73, 2643-2661.

Parker, R. L. and D. W. Oldennburg, 1973, Thermal Model of Oceanic Ridges, Nature, Phys. Sci., 242, 137-139.

Reveld, R. and A. E. MAXwell, 1952, Heat Flow through the Ocean Floor, Nature, 170, 199-200.

Schlue, J. W. and L. KNopoff, 1976, Shear Wave Anistropy in the Upper Mantle of the Pacific Basin, Geophys. Res. Lett., 3, 359-362.

Sclater, J. G. and J. Francheteau, 1970, The Implication of Terrestrical Heat Flow Observations on Current Tectonic and Geochemical Models of the Crust and Upper Mantle of the Earth, Geophys. J. Roy. Astr. Soc., 20, 509-542.

Sclater, J. G., R. P. Von Herzen, D. L. Williams, R. N. Anderson and K. Klitgord, 1974, The Galapagos Spreading Center: Heat-Flow low on the North Flank, Geophys. J. Roy. Astron. Soc., 38, 609-626.

Sclater, J. G. and J. Crowe, 1976, On the Reliability of Oceanic Heat Flow Averages, J. Geophys. Res., 81, 2997-3006.

Uyeda, S. and A. Mryashiro, 1974, Plate Tectonics and the Japanese Islands: A Synthesis, Geol. Soc, America Bull, 85, 1159-1170. 
Von Herzen, R. P. and S. Uyeda, 1963, Heat Flow through the Eastern Pacific Floor, J. Geophys. Res. 68, 4219-4250.

Yasui, M., T. Kishir, T. Watanabe and S. UyedA, 1967, Heat Flow in the Sea of Japan, in the Crust and Upper Mantle of the Pacific area, Geophys. monogr. No. 12, Amer. Geophys. Un., 3-16.

YoshII, T., 1973, Upper Mantle Structure beneath the North Pacific and the Marginal Seas, J. Phys. Earth., 21, 313-328.

吉井敏勊，河野芳輝，伊東敬祐，1975，海洋ブレートの構造，科学，45，330-335.

YoshII, T., 1975, Regionality of Group Velocities of Rayleigh Waves in the Pacific and Thickening of the Plate, Earth Planet. Sci. Lett., 25, 305-312.

YoshII, T., Y. KoNo and K. ITo, 1976, Thickening of the Oceanic Lithosphere in the Geophysics of the Pacific Ocean Basin and its Margin. The Woolard Volume. Geophys. Monog. 19, Am. Geophys. Union, 424-430. 